\title{
Correction to: Book review: Baruch B. Schwarz and Michael J. Baker (Foreword by L. B. Resnick with F. Schantz) (2017) Dialogue, Argumentation and Education: History, Theory and Practice New York: Cambridge 316 pages Hardback ISBN 978-1-107-14181-0 RRP \$110
}

\section{Keith Weber ${ }^{1}$}

\section{Correction to: Educ Stud Math}

$$
\text { https://doi.org/10.1007/s10649-017-9780-5 }
$$

The title of the book review incorrectly identifies the book's authors as Editors. The correct title of the review is:

Book review: Baruch B. Schwarz and Michael J. Baker (Foreword by L. B. Resnick with F. Schantz) (2017) Dialogue, Argumentation and Education: History, Theory and Practice 